\title{
FINANCIAL PERFORMANCE OF EPONYMOUS FIRMS IN THE CZECH REPUBLIC
}

\section{Ondřej Machek, Martin Machek, Michele Stasa*}

\begin{abstract}
Past literature suggests that firms that bear the name of the owners, also known as eponymous firms, have superior profitability. The goal of this paper is to test the differences in the financial performance indicators between eponymous and other Czech firms. In a sample of 17,833 privately held firms operating in the Czech Republic, owned by Czech individuals or families and having complete financial data for 2014-2017, we find that eponymous firms have a significantly higher return on assets. However, no difference in return on equity has been found. We also show that eponymous firms have lower asset turnover and labour productivity, use less debt financing and have greater liquidity. In this sense, their financial characteristics are close to those of family businesses. Overall, eponymous firms are younger than other firms, but there are no significant differences in the size of the firms. The results suggest that firms named after the founder are more likely to perform well.
\end{abstract}

Keywords: eponymous firms, financial performance, Czech Republic

JEL Classification: M30, M31

\section{Introduction}

The choice of a firm's name is a deliberate process where the aim may be to inform consumers, for example, about the quality or price of the product (McDevitt, 2014) or to present a particular social identity (Belenzon et al., 2017). At the same time, according to Tadelis (1999), a firm is a "bearer of reputation". In some firms, founders decide to name their company after themselves. These eponymous firms have been found to be empirically different from other companies.

For example, Gompers et al. (2009) found that insiders in eponymous firms placed a high value on the private benefits of control, i.e. the benefits available only to large shareholders; naming a firm after the founder indicates a personal stake in the business. Bach and Serrano-Velarde (2015) assumed that eponymous firms were family businesses and used the match between CEO surname and firm name to show that in eponymous firms, there is a stronger propensity to dynastic succession. In a recent study, Belenzon et al. (2017) showed that eponymy is related to superior profitability as measured by the return on assets. The authors assume that eponymy creates a link between the founder and the firm, which results in reputational concerns.

Overall, there is very little literature available when it comes to eponymous firms. One of the first studies devoted exclusively to this topic is the paper by Belenzon et al. (2017). In their dataset based on Western European countries, $12 \%$ to $13 \%$ of firms bore

* Faculty of Business Administration, University of Economics, Prague (ondrej.machek@vse.cz, martin.machek@vse.cz,stam02@vse.cz). 
the owner's name. Eponymy is not uncommon and deserves academic attention. Past authors, including Belenzon et al. (2017), focused on Western European countries, thus neglecting Central and Eastern European (CEE) countries, which have a different historical development. After the fall of the Iron Curtain in 1989, many new firms were founded in an undeveloped economic and financial environment and often without any knowledge about the functioning of a market economy. Many of these firms still exist and compete with newly established companies or foreign business subsidiaries. There is no evidence to date on the properties of eponymous firms in CEE countries.

To address the research gap, we aim to test the differences in financial performance indicators between eponymous and other Czech firms. The remainder of this paper first elaborates on the relevant theoretical background then subsequently presents the materials and methods used in the study. The results and discussion are then presented before the concluding remarks.

\section{Theoretical Framework}

The decision on a firm's name is a crucial strategic choice as it provides important information to the stakeholders. For instance, consumers and suppliers are informed of the quality, reputation and historical performance. Moreover, the linguistic characteristics of the name may subconsciously affect consumers' decision making. Most of the existing research addresses the effect of alphabetical order on the firms' performance. Arbatskaya (2007) introduced the model of ordered search, in which the firms' prices and revenues decrease with their position in the alphabetical list. Several studies have supported their findings. McDevitt (2014) found that firms whose names begin with "A" offer lower quality (as measured by the number of complaints) while charging higher prices. Similar results have been presented by Jacobs and Hillert (2016) showing shares at the beginning of the alphabetical lists were characterised by more active trading, higher liquidity and evaluation. The disadvantageous position at the end of the alphabet was also confirmed by Hanousek and Jurajda (2018) in a sample of European firms. The authors also investigated the effect of plosives in the firms' names on the performance; however, no significant relationship has been found. Nevertheless, brand names with initial plosives were found more memorable (Van den Bergh et al., 1987; Lowrey et al., 2013). Generally, firms with shorter and easy-to-pronounce names have more owners, greater trade activity, liquidity and performance (Green and Jame, 2013). Other studies investigated the effect of names containing a national or English word. National company names positively affected performance in countries speaking Slavic and Romanic languages, Scandinavian countries, Ireland, Germany (Hanousek and Jurajda, 2018) as well as in the US (Benos and Joches, 2013). The use of English words in firms' names also has a positive impact on revenues in ex-Eastern bloc Slavic countries due to the consumer perception of "western quality", whereas this negatively impacts revenues in strongly-patriotic France, Portuguese, Spain and Romania (Hanousek and Jurajda, 2018).

As to eponymy, the literature has been almost silent on the subject. A firm's name is closely related to reputational dynamics (Tadelis, 1999). To elaborate on the reputational dynamics of eponymous firms, Belenzon et al. (2017) explain the choice of a firm's name using the economic theory. Using an individual's name when naming a firm is associated with costs; the failure of the firm will be perceived by consumers as a failure of this individual, which, in turn, will reduce this individual's future payoffs. To explain 
why under such circumstances people are willing to put their name on a company, Belenzon et al. (2017) argue that some owners seek to tie their own identity to the firm name; such individuals will gain utility from actions that support their identity. However, as a result, when a firm bears the name of the owner, strong reputation concerns are likely to emerge (Belenzon et al., 2017). Minichilli et al. (2018) added that eponymous firms are associated with a higher quality of financial reporting and lower cost of debt. Independence of the management's reward system on the financial outcomes is considered to be the main supporting factor.

Many of the above findings apply to family businesses, and eponymous firms can indeed be similar to family firms in many aspects. One of the paradigms of family business literature is the socioemotional wealth theory (Berrone et al., 2012), which assumes that family firms do not strictly follow economic goals and explains why family businesses are different from their non-family counterparts. Berrone et al.'s (2017) FIBER acronym describes five dimensions of socioemotional wealth (SEW): family control and influence, identification of family members with the firm, binding social ties, emotional attachment of family members, and the renewal of family bonds to the firm through dynastic succession. The similarity between eponymous and family firms can also be supported by several studies focusing on eponymous family businesses. Kashmiri and Mahajan (2010) attribute their superior performance to the greater emphasis on strategic planning, CSR activities and customer orientation. The authors further found evidence of a higher shareholder value of product innovation announcements due to their reputational concerns (Kashimiri and Mahajan, 2014), which is in line with the arguments of Zellweger et al. (2010) that the reputational concerns result from the identification of family members with the firm and the attempt to avoid the costs of failure. On the contrary, Brockman et al. (2017) found the negative impact of eponymous naming on the family business value measured by Tobin's q due to the endowment effect. However, Tobin's q may not be a reliable performance measure (Dybvig and Warachka, 2016).

For our research on eponymous firms, the key dimension of SEW is the "identification with the firm". When the identity of the family (owner) is tied to the firm, the family (owner) may see the firm as an extension of themselves. Under such circumstances, the success of the firm will be perceived as the success of the individual, owners will be proud to state that they are part of the firm, and customers will associate the individual's name with the products and services (Berrone et al., 2012).

According to Zellweger et al. (2013), the organisational identity theory assumes that individuals who are visibly associated with the firm are often reminded of their organizational membership and the link between the individual and the firm is stressed. At the same time, it is presumable that the strongest link is created by putting one's name to the company. High visibility of the individual will be positively related to the individual's concern for corporate reputation (Zellweger et al., 2013). As a result, there are several reasons why eponymous firms should overperform. First, in firms with high identification, owners will tend to build a positive reputation (Berrone, et al. 2010; Deephouse and Jaskiewicz, 2012; Zellweger et al., 2013). Given the expectations of the public, eponymous firms will "act accordingly and deliver proven quality and service" (Zellweger et al., 2013). Second, intensified monitoring of managers (Gompers et al., 2009) will reduce agency costs, which can be a source of better performance. 
The fear of reputation damage in the case of financial distress may be closely related to risk aversion and more prudent financial management. Family firms have frequently been reported to use less debt financing (Allouche et al., 2008) and to have greater liquidity (Machek and Hnilica, 2015), which increases financial security but limits growth opportunities. Just like family firms have been repeatedly found to grow less than non-family firms (Belenzon et al., 2015; Hnilica et al., 2016), it appears that eponymous firms also grow less than non-eponymous firms: they exchange "growth for glory" (Belenzon et al., 2019).

This paper addresses the following research question: What are the performance gaps between eponymous and other Czech firms? To address the question, we focus on selected financial ratios: profitability, asset management, liquidity and level of debt; most of which are not yet documented in the literature.

\section{Materials and Methods}

To sample the firms, we used the Bureau van Dijk's Amadeus database. We searched for all limited liability firms located in the Czech Republic that are owned by one or more Czech named individuals or families and which have complete financial data for 2014-2017. The final sample contains 17,833 companies. Subsequently, we searched for matches between the firm name and the surnames of the shareholders. There are 1947 eponymous firms in the sample, which equates to $10.197 \%$. In this respect, the proportion of eponymous firms in our sample is similar to the sample of Belenzon et al. (2017).

To test the financial differences, we used six multiple linear regressions performed in Stata 14. To address the heteroskedasticity issues, we used linear regressions with robust estimators. The following indicators have been used as dependent variables:

- Return on assets (P/L before taxation over total assets).

- Return on equity (P/L after taxes over shareholders' funds).

- Asset turnover (revenue over total assets).

- Current ratio (current assets over current liabilities).

- Gearing (debt-to-equity ratio).

- Labour productivity (profit per employee).

An eponymous firm is a binary variable taking the value of one when the name of the firm contains the surname of one of the owners. To reflect the potential maturation effects on financial indicators, we used the age of the firm (current year minus year of incorporation) as an independent variable. Likewise, to capture scale effects, we used the size of the firm (natural logarithm of total assets). To account for industry effects, we used thirteen industry dummy variables (see Table 1).

\section{Results and Discussion}

Table 1 shows the industry affiliation of the firms in the sample, both for eponymous firms and other firms. The differences are not particularly significant; most firms operate in the NACE sector G ("Wholesale and retail trade; repair of motor vehicles and motorcycles"), followed by sector C ("Manufacturing") and F ("Construction"). Several industries are only represented marginally (such as electricity suppliers or financial and insurance activities). 
Table 1 | Industry affiliation of the firms in the sample

\begin{tabular}{|c|c|c|c|c|}
\hline \multirow[b]{2}{*}{ Industry affiliation } & \multicolumn{2}{|c|}{ Absolute frequencies } & \multicolumn{2}{|c|}{ Relative frequencies } \\
\hline & $\begin{array}{l}\text { Eponymous } \\
\text { firms }\end{array}$ & $\begin{array}{l}\text { Other } \\
\text { firms }\end{array}$ & $\begin{array}{l}\text { Eponymous } \\
\text { firms }\end{array}$ & $\begin{array}{l}\text { Other } \\
\text { firms }\end{array}$ \\
\hline Agriculture, forestry and fishing & 45 & 445 & $2.30 \%$ & $2.80 \%$ \\
\hline Manufacturing & 354 & 3018 & $18.20 \%$ & $19.00 \%$ \\
\hline $\begin{array}{l}\text { Electricity, gas, steam and air } \\
\text { conditioning supply }\end{array}$ & 8 & 16 & $0.40 \%$ & $0.10 \%$ \\
\hline $\begin{array}{l}\text { Water supply; sewerage; waste } \\
\text { management }\end{array}$ & 14 & 127 & $0.70 \%$ & $0.80 \%$ \\
\hline Construction & 300 & 2018 & $15.40 \%$ & $12.70 \%$ \\
\hline $\begin{array}{l}\text { Wholesale and retail; repair of motor } \\
\text { vehicles/motorcycles }\end{array}$ & 424 & 4114 & $21.80 \%$ & $25.90 \%$ \\
\hline Transportation and storage & 160 & 635 & $8.20 \%$ & $4.00 \%$ \\
\hline $\begin{array}{l}\text { Accommodation and food service } \\
\text { activities }\end{array}$ & 33 & 381 & $1.70 \%$ & $2.40 \%$ \\
\hline Information and communication & 29 & 715 & $1.50 \%$ & $4.50 \%$ \\
\hline Financial and insurance activities & 2 & 48 & $0.10 \%$ & $0.30 \%$ \\
\hline Real estate activities & 37 & 556 & $1.90 \%$ & $3.50 \%$ \\
\hline $\begin{array}{l}\text { Professional, scientific and technical } \\
\text { activities }\end{array}$ & 204 & 2081 & $10.50 \%$ & $13.10 \%$ \\
\hline $\begin{array}{l}\text { Administrative and support service } \\
\text { activities }\end{array}$ & 27 & 429 & $1.40 \%$ & $2.70 \%$ \\
\hline Other & 310 & 1303 & $15.90 \%$ & $8.20 \%$ \\
\hline
\end{tabular}

Source: Authors`own processing

Table 2 shows the descriptive statistics, again both for eponymous and other firms. The minimum and maximum values suggest the presence of influential observations; however, since these values are real and not due to measurement errors, we have not removed them from the sample.

The matrix of Pearson correlations among the variables is shown in Table 3. Due to a large number of observations, there are many pairwise correlations that are statistically significant at the 0.01 level. The first column is the most relevant as it indicates the correlation of eponymy (EPO) with the other variables. There are significant albeit weak positive correlations between EPO and return on assets and return on equity. Likewise, there are significant negative correlations between EPO and asset turnover and the age of the firm. 
Table 2 | Descriptive statistics

\begin{tabular}{|l|r|c|c|c|c|c|c|c|}
\hline & \multicolumn{5}{|c}{ Eponymous firms } & \multicolumn{3}{c|}{ Other firms } \\
\hline & Mean & SD & Min & Max & Mean & SD & Min & Max \\
\hline ROA & 12.747 & 16.785 & -72.568 & 91.828 & 9.623 & 13.446 & -69.230 & 98.819 \\
\hline ROE & 19.980 & 34.469 & -408.688 & 244.870 & 16.490 & 31.678 & -357.45 & 301.553 \\
\hline AT & 4.786 & 6.358 & 0.077 & 88.855 & 5.621 & 11.158 & 0.002 & 329.318 \\
\hline CR & 4.901 & 6.504 & 0.024 & 64.954 & 4.591 & 6.168 & 0.010 & 89.417 \\
\hline GE & 43.279 & 81.759 & 0.000 & 761.360 & 44.651 & 86.303 & 0.000 & 799.278 \\
\hline LP & 6.470 & 12.744 & -17.839 & 292.635 & 6.777 & 19.245 & -57.357 & 1008.725 \\
\hline Size & 8.871 & 1.688 & 4.314 & 14.170 & 8.938 & 1.689 & 3.466 & 16.630 \\
\hline Age & 12.231 & 6.669 & 3.000 & 27.000 & 15.249 & 7.040 & 3.000 & 28.000 \\
\hline
\end{tabular}

Source: Authors` own processing

Note: $\mathrm{ROA}=$ return on assets; $\mathrm{ROE}$ = return on equity; $\mathrm{AT}$ = asset turnover; $\mathrm{CR}=$ current ratio; $\mathrm{GE}$ = gearing; $\mathrm{LP}=$ labour productivity.

Table 3 | Correlation matrix

\begin{tabular}{|l|c|c|c|c|c|c|c|c|}
\hline & EPO & ROA & ROE & AT & CR & GE & LP & Size \\
\hline ROA & $0.070^{*}$ & 1 & & & & & & \\
\hline ROE & $0.034^{*}$ & $0.699^{*}$ & 1 & & & & & \\
\hline AT & $-0.024^{*}$ & $-0.078^{*}$ & $-0.024^{*}$ & 1 & & & & \\
\hline CR & 0.015 & $0.106^{*}$ & $-0.024^{*}$ & $-0.185^{*}$ & 1 & & & \\
\hline GE & 0.005 & $-0.168^{*}$ & 0.010 & $0.087^{*}$ & $-0.145^{*}$ & 1 & & \\
\hline LP & 0.005 & $0.334^{*}$ & $0.252^{*}$ & $-0.045^{*}$ & $0.077^{*}$ & $-0.053^{*}$ & 1 & \\
\hline Size & 0.012 & $-0.042^{*}$ & $0.056^{*}$ & $-0.073^{*}$ & $-0.1208^{*}$ & $0.164^{*}$ & $0.239^{*}$ & 1 \\
\hline Age & $-0.133^{*}$ & $-0.212^{*}$ & $-0.162^{*}$ & $-0.095^{*}$ & $-0.020^{*}$ & $-0.051^{*}$ & 0.013 & $0.369^{*}$ \\
\hline
\end{tabular}

Source: Authors` own processing

Note: * - significant at $0.01 ; \mathrm{EPO}=$ eponymous firm; ROA = return on assets; ROE = return on equity; $\mathrm{AT}=$ asset turnover; $\mathrm{CR}=$ current ratio; $\mathrm{GE}=$ gearing; $\mathrm{LP}=$ labor productivity.

To compare eponymous firms with other firms, we first used the Student's t-test with unequal variances (see Table 4). The results indicate several statistically significant differences: on average, eponymous firms appear to have a higher return on assets and return on equity. They also appear to have a lower asset turnover and current ratio and to be younger than other companies. 
Table 4 | Test for mean differences

\begin{tabular}{|l|c|c|c|c|}
\hline Variable & Eponymous firms & Other firms & t-statistics & p-value \\
\hline ROA & 12.747 & 9.623 & $-7.908^{* * *}$ & $<0.001$ \\
\hline ROE & 19.980 & 16.490 & $-4.254^{* * *}$ & 0.001 \\
\hline AT & 4.786 & 5.621 & $3.240^{* * *}$ & 0.038 \\
\hline CR & 4.900 & 4.591 & $-2.076^{* *}$ & 0.506 \\
\hline GE & 43.279 & 44.651 & 0.666 & 0.493 \\
\hline LP & 6.470 & 6.777 & 0.685 & 0.098 \\
\hline Size & 8.871 & 8.938 & $1.654^{*}$ & $<0.001$ \\
\hline Age & 12.230 & 15.249 & $17.953^{* * *}$ & \\
\hline
\end{tabular}

Source: Authors` own processing

Note: *** - significant at $0.01 ; * *$ - significant at $0.05 *$ - significant at 0.1 ; EPO = eponymous firm; $\mathrm{ROA}=$ return on assets; $\mathrm{ROE}=$ return on equity; $\mathrm{AT}=$ asset turnover; $\mathrm{CR}=$ current ratio; $\mathrm{GE}=$ gearing; $\mathrm{LP}=$ labour productivity.

To test the effects of eponymy while considering control variables, we used multiple linear regression for six outcome variables (see Table 5). As expected, eponymous firms have a higher return on assets, and hence are more profitable. This finding is consistent with the study of Belenzon et al. (2017). On the other hand, no significant effect of eponymy on return on equity has been found. Instead, the seemingly higher return on equity of eponymous firms, which was suggested by a simple comparison of means, can be explained by the fact that eponymous firms are younger (age affects ROE negatively). The difference may also be due to the effects of the industries in which these firms operate.

\section{Table 5 | Regression results}

\begin{tabular}{|l|c|c|c|c|c|c|}
\hline Variable & ROA & ROE & AT & CR & GE & LP \\
\hline EPO & $1.191^{* * *}$ & -0.096 & $-1.198^{* * *}$ & $0.367^{* *}$ & $-5.442^{* * *}$ & $-0.751^{* *}$ \\
\hline Size & $0.740^{* * *}$ & $2.991^{* * *}$ & $-0.373^{* * *}$ & $-0.402^{* * *}$ & $9.737^{* * *}$ & $3.437^{* * *}$ \\
\hline Age & $-0.373^{* * *}$ & $-0.886^{* * *}$ & $-0.136^{* * *}$ & $0.033^{* * *}$ & $-1.658^{* * *}$ & $-0.309^{* * *}$ \\
\hline Constant & $19.988^{* * *}$ & $16.332^{* * *}$ & $9.043^{* * *}$ & $9.034^{* * *}$ & $-30.264^{* * *}$ & $-17.148^{* * *}$ \\
\hline & & & & & & \\
\hline F-test & $92.36^{* * *}$ & $65.70^{* * *}$ & $29.92^{* * *}$ & $30.68^{* * *}$ & $54.98^{* * *}$ & $48.15^{* * *}$ \\
\hline$R^{2}$ & 0.121 & 0.068 & 0.030 & 0.026 & 0.052 & 0.089 \\
\hline
\end{tabular}

Source: Authors` own processing

Note: ${ }^{* *}$ - significant at $0.01 ;{ }^{* *}$ - significant at 0.05 . Industry dummies are not displayed. $\mathrm{EPO}=$ eponymous firm; $\mathrm{ROA}=$ return on assets; $\mathrm{ROE}=$ return on equity; $\mathrm{AT}$ = asset turnover; $\mathrm{CR}=$ current ratio; $\mathrm{GE}=$ gearing; $\mathrm{LP}=$ labour productivity. 
Our results also suggest that there is a significant negative relationship between eponymy and asset turnover, even after controlling for the industry. This suggests that eponymous firms are less efficient in asset utilisation: with a given level of assets, they generate less revenue. A similar finding has been found for labour productivity: with a given number of employees, eponymous firms generate a lower level of earnings.

Eponymous firms also appear to use less debt and keep more liquid assets. These findings suggest that eponymous firms have several similarities to family businesses; they are more risk-averse, hence relying more on shareholders' capital, to avoid the risk of financial distress. In particular, the pride related to using their own family name may result in fear of damaging the family's (or their own) reputation. This theory is also supported by their greater liquidity. Keeping more liquid assets is a sign of more conservative financial management policy, which is typical for family firms (Allouche et al., 2008; Machek and Hnilica, 2015); greater current ratio improves the ability to settle shortterm obligations, hence reducing the risk of insolvency. However, this approach is more expensive regarding economic costs; a firm keeps more inventory than required, which increases the maintenance costs, and liquid assets generally generate a lower return on investment. Hence, we argue that firm eponymy implies risk aversion and financial conservatism, which are due to reputational concerns.

Since the return on equity can be decomposed into return on sales, asset turnover and an equity multiplier, which is a measure of the level of debt (Stowe et al., 2002), we can formulate the explanation why eponymous firms do not overperform in terms of return on equity. They have a greater profit margin (which indicates a better ability to set higher prices or manage costs), but a lower asset turnover and use less debt. Hence, the positive effects of profitability will be offset by the reluctance to use debt and by a lower asset utilisation efficiency.

Several other observations stand out from the analysis. First, larger firms are more profitable and have better labour productivity although they have a lower asset turnover and use more debt and fewer liquid assets. These findings can be attributed to economies of scale and professionalisation of management. Second, older firms tend to be less profitable, have a lower asset turnover and worse labour productivity, which may be a result of maturation effects. On the other hand, they use less debt and more liquid assets.

\section{Conclusion}

The existing literature frequently mentions that firms that bear the name of the owner are more profitable. The goal of this paper was to explore the financial performance of eponymous Czech firms. According to our results, it is true that eponymous Czech firms are more profitable in terms of return on assets. However, this appears to be untrue from the return on equity perspective. At the same time, the return on equity is likely to be the most important financial ratio an investor should consider. We also found that eponymous firms have a lower asset turnover and labour productivity, which suggests that they use their resources less efficiently. Moreover, we found that eponymous firms use less debt and have greater liquidity.

There are several theoretical and practical contributions to this paper. First, there is no evidence in the literature about the working capital management of eponymous firms. Second, we found that eponymous firms represent more than $10 \%$ of all Czech firms, and hence their economic significance is not marginal; eponymy is not to be associated 
with very small firms since the size of eponymous firms does not particularly differ from other firms. The fact that the match between the founder's name and the name of the firm implies a greater probability of having superior profitability may be used by entrepreneurs when deciding about the name of their firm. Third, like Belenzon et al. (2017), we argue that eponymy may be an interesting variable when considering future entrepreneurship and strategy studies.

However, despite our best efforts, this study also has limitations. First, we had to rely on the credibility of the data extracted from the BvD Amadeus Database. Although the database has been used by many previous authors, there are several pitfalls; in particular, the number of employees is not a precise number, but the centre of an interval. Hence, the data on labour productivity may be biased. Second, not all companies are listed in this database, which may result in under coverage of certain groups of firms.

In our discussion, we often refer to family business literature. Indeed, many eponymous firms can be purely family firms. Hence, some of the differences found in this study can be attributed to the unique attributes of family firms. In other words, eponymy may be an intervening variable between "familiness" and financial performance.

Finally, further research is required in this area. It would be interesting to investigate the properties of eponymous firms not only in other Central and Eastern European countries but also in other cultures since the effect of cultural context on the eponymyperformance relationship is yet unknown. Second, the theory says little about what type of entrepreneurs decide to put their name on the business; their personality traits (such as egoism or entrepreneurial orientation) are yet unexplored. Third, the current trends in naming conventions are not evident; do the current start-ups or high-growth firms prefer other types of firm names, and if so, what are these trends? Overall, future research should consider in-depth how more naming conventions affect firm performance, from both the economic and the non-economic aspect.

\section{References}

Allouche, J., Amann, B., Jaussaud, J., \& Kurashina, T. (2008). The Impact of Family Control on the Performance and Financial Characteristics of Family Versus Nonfamily Businesses in Japan: A Matched-Pair Investigation. Family Business Review, 21(4), pp. 315-329. https://doi.org/10.1177/08944865080210040104

Anderson, R., Mansi, S. A., \& Reeb, D. M. (2003). Founding Family Ownership and the Agency Cost of Debt. Journal of Financial Economics, 68(2), pp. 263-285. https://doi.org/10.1016/S0304-405X(03)00067-9

Arbatskaya, M. (2007). Ordered Search. The RAND Journal of Economics, 38(1), pp. 119-126. https://doi.org/10.1111/j.1756-2171.2007.tb00047.x

Bach, L., \& Serrano-Velarde, N. (2015). CEO Identity and Labor Contracts: Evidence from CEO Transitions. Journal of Corporate Finance, 33, pp. 227-242. https://doi.org/10.1016/j.jcorpfin.2015.01.009

Belenzon, S., Patacconi, A., \& Zarutskie, R. (2016). Married to the Firm? A Large-Scale Investigation of the Social Context of Ownership. Strategic Management Journal, 37(13), pp. 2611-2638. https://doi.org/10.1002/smj.2441

Belenzon, S., Chatterji, A., \& Daley, B. (2017). Eponymous Entrepreneurs. American Economic Review, 107(6), pp. 1638-1655. https://doi.org/10.1257/aer.20141524 
Belenzon, S., Chatterji, A., \& Daley, B. (2019). Choosing between Growth and Glory. Management Science [online first]. https://doi.org/10.1287/mnsc.2019.3296

Benos, E., \& Jochec, M. (2013). Patriotic Name Bias and Stock Returns. Journal of Financial Markets, 16(3), pp. 550-570. https://doi.org/10.1016/j.finmar.2012.10.002

Berrone, P., Cruz, C., Gomez-Mejia, L. R., \& Larraza-Kintana, M. (2010). Socioemotional Wealth and Corporate Responses to Institutional Pressures: Do Family-Controlled Firms Pollute Less? Administrative Science Quarterly, 55, pp. 82-113.

https://doi.org/10.2189/asqu.2010.55.1.82

Berrone, P., Cruz, C., \& Gomez-Mejia, L. R. (2012). Socioemotional Wealth in Family Firms: Theoretical Dimensions, Assessment Approaches, and Agenda for Future Research. Family Business Review, 25(3), pp. 258-279. https://doi.org/10.1177/0894486511435355

Brockman, P., Lee, H. S., Megginson, W. L., \& Salas, J. M. (2017). It's All in the Name: Evidence of Founder-Firm Endowment Effects. [online] clsbluesky.law.columbia.edu. Available at: http://clsbluesky.law.columbia.edu/2017/04/20/its-all-in-the-name-evidence-of-founderfirm-endowment-effects [Accessed 2 Apr. 2019]

Deephouse, D. L., \& Jaskiewicz, P. (2012). Do Family Firms Have Better Reputations Than NonFamily Firms? An Integration of Socio-Emotional Wealth and Social Identity Theories. Journal of Management Studies, 50(3), pp. 337-360. https://doi.org/10.1111/joms.12015

Dybvig, P. H., \& Warachka, M. (2016). Tobin's Q Does Not Measure Firm Performance: Theory, Empirics, and Alternative Measures [online]. Available at: http://ssrn.com/abstract=1562444 [Accessed 2 Apr. 2019]

Gompers, P. A., Ishii, J., \& Metrick, A. (2009). Extreme Governance: An Analysis of Dual-Class Firms in the United States. The Review of Financial Studies, 23(3), pp. 1051-1088. https://doi.org/10.1093/rfs/hhp024

Green, T. C., \& Jame, R. (2013). Company Name Fluency, Investor Recognition, and Firm Value. Journal of Financial Economics, 109(3), pp. 813-834. https://doi.org/10.1016/j.jfineco.2013.04.007

Hanousek, J., \& Jurajda, Š. (2018). Názvy společností a jejich vliv na výkonnost firem [Corporate Names and Performance]. Politická ekonomie, 66(6), pp. 671-688. https://doi.org/10.18267/j.polek.1218

Hnilica, J., Machek, O., \& Lukeš, M. (2016). Are Family Firms More Stable? Evidence from the Czech Republic [conference paper]. Rencontres de St-Gall 2016 - Institutional Context and Governance of SMEs and Family Firms: Trends and Challenges. St. Gallen, 28. Aug. 2016 - 31. Aug. 2016. St. Gallen: University of St. Gallen.

Jacobs, H., \& Hillert, A. (2016). The Power of Primacy: Alphabetic Bias, Investor Recognition, and Trading Behavior. Review of Finance, 20(2), pp. 693-723. https://doi.org/10.1093/rof/rfv060

Kashmiri, S., \& Mahajan, V. (2010). What's in a Name? An Analysis of the Strategic Behavior of Family Firms. International Journal of Research in Marketing, 27, pp. 271-280. https://doi.org/10.1016/j.ijresmar.2010.04.001

Kashmiri, S., \& Mahajan, V. (2014). A Rose by Any Other Name: Are Family Firms Named After Their Founding Families Rewarded More for Their New Product Introductions? Journal of Business Ethics, 124(1), pp. 81-99. https://doi.org/10.1007/s10551-013-1861-5

Lowrey, T. M., Shrum, L. J., \& Dubitsky, T. M. (2013). The Relation between Brand-Name Linguistic Characteristics and Brand-Name Memory. Journal of Advertising, 32(3), pp. 7-17. https://doi.org/10.1080/00913367.2003.10639137 
Machek, O., \& Hnilica, J. (2015). Hodnocení vlivu zastoupení rodiny ve vlastnické a rídící struktuře firem na jejich finanční výkonnost pomocí metody zkoumání shody párů [Evaluating the Impact of Family Presence in Ownership and Management on Financial Performance of Firms Using Matched-Pair Investigation]. Politická ekonomie, 63(3), pp. 347-362. https://doi.org/10.18267/j.polek.1007

McDevitt, R. C. (2014). "A" Business by Any Other Name: Firm Name Choice as a Signal of Firm Quality. Journal of Political Economy, 122(4), pp. 909-944. https://doi.org/10.1086/676333

Minichilli, A., Prencipe, A., Radhakrishnan, S., \& Siciliano, S. (2018). What's in a Name? Eponymous Private Firms and Financial Reporting Quality. [online] ceibs.edu. Available at: http://www.ceibs.edu/node/16653 [Accessed 23 Mar. 2019]

Stowe, J. D., Robinson, T. R., Pinto, J. E., \& McLeavy, D. W. (2002). Analysis of Equity Investments: Valuation. Baltimore: AIMR.

Vanden Bergh, B., Adler, K., \& Oliver, L. (1987). Linguistic Distinction among Top Brand Names. Journal of Advertising Research, 27(4), pp. 39-44.

Tadelis, S. (1999). What's in a Name? Reputation as a Tradeable Asset. The American Economic Review, 89(3), pp. 548-563. https://doi.org/10.1257/aer.89.3.548

Zellweger, T. M., Eddleston, K. A., \& Kellermanns, F. W. (2010). Exploring the Concept of Familiness: Introducing Family Firm Identity. Journal of Family Business Strategy, 1(1), pp. 54-63. https://doi.org/ 10.1016/j.jfbs.2009.12.003

Zellweger, T. M., Nason, R. S., Nordqvist, M., \& Brush, C. G. (2013). Why Do Family Firms Strive for Nonfinancial Goals? An Organizational Identity Perspective. Entrepreneurship Theory and Practice, 37(2), pp. 229-248. https://doi.org/10.1111/j.1540-6520.2011.00466.x 